\title{
TENDENCIES FOR THE DEVELOPMENT OF HOTELS IN UKRAINE UNDER CRISIS SITUATIONS
}

\section{Konon Bagrii}

Chernivtsi Institute of Trade and Economics of Kyiv National University of Trade and Economics, Chernivtsi, Ukraine

\section{Karina Palamarek}

Chernivtsi Institute of Trade and Economics of Kyiv National University of Trade and Economics, Chernivtsi, Ukraine

\section{CMESTE}

JEL Category: M11, 032

\begin{abstract}
Any economic crisis leads to increased risks, increased competition and deterioration of the financial position of many hospitality businesses. A weak hotel management system, inadequate customer relationships, and revenue management often trigger the crisis of the hotel business. The adverse economic environment is forcing hotel managers to revise their development strategy, namely, to optimize their operations by reducing costs and using marketing tools. Those enterprises that manage to reduce costs without losing the quality of the services provided are in the most demand and competitive in a crisis. Improving the quality of the hotel offer to the level of international standards, expanding markets and training specialists in accordance with the requirements of world standards is indispensable to ensure the development of tourism in the context of deepening relations between Ukraine and the European Union. The development strategy of the industry requires state financial support in the main areas: attracting tourists to selected target markets; bringing national standards, safety standards, quality of goods and services in line with international requirements. In the article, the authors form their own point of view on the efficiency of functioning of the hotel enterprise in a crisis. The authors study the main trends in the development of the hotel business; analyze the hotel business in Ukraine based on statistics and expert opinions. The methods of management of the hotel enterprise during the crisis are presented. The authors have developed a three-level model of functioning of hotel enterprises in Ukraine in times of crisis, which will help to improve the financial situation for managers and managers of hotel enterprises in times of crisis.
\end{abstract}

Keywords: hotel enterprise, crisis, management, hotel business, crisis management, analysis, strategic management.

Address of the corresponding author:

Konon Bagrii

麦=kononbagriy@gmail.com 


\section{INTRODUCTION}

The economic crisis is affecting all areas of business, including the hospitality business. Developing an effective development plan is the primary way of surviving a hospitality business in an unfavorable economic environment. The problem of hospitality business development in times of economic crisis has become an urgent task for hotel business owners in the international market. Thus, the purpose of this study is to attempt to form a model of functioning of a hotel enterprise that may take place in the international tourism market in times of crisis. A literature review of the subject shows that the vast majority of authors consider the problems of crisis management and effective management of the enterprise as a whole, without a sectoral sign. (Shad, K., \& Fong Woon, L., 2015).

One of the definitions of crisis management, which J. Darling refers to says: "Crisis management is defined as a set of functions or processes for identifying, studying and forecasting crisis problems and outlines specific ways that would allow an organization to prevent or deal with a crisis." (Essays, 2018).

P. Lagadec believes that "effective crisis management practices are needed to avoid or reduce such unforeseen impacts." As the economic environment grows in complexity and uncertainty, crisis management policies require considerable effort for organizations to learn, and on the other hand, help organizations to determine the determinants of their ability to survive or adapt. (Kopia, J., Just, V., Geldmache, W., \& Bußian, A., 2017).

If we talk about a particular industry - in this case, hospitality business, many modern researchers, considering the management of the hotel business in times of crisis, believe that, first of all, we should dwell on the conditions of operation of the hotel business enterprises. First, these are measures to increase sales by forming new hotel products and changing pricing, and second, measures to optimize costs, as these are taken from the best practices of successful hospitality businesses. This opinion is undoubtedly relevant, but it should be noted that the main task in the operation of the hotel company in times of crisis is to maintain competitiveness.

According to $\mathrm{Y}$. Zemlina and O. Lifirenko an important aspect directly related to the emergence of a crisis within the hotel business is the lack of professional qualifications of employees, which entails accountability to owners for the consequences of management decisions and the financial result of operations. (Zemlina, Y., \& Lifirenko, O., 2019)

In our opinion, the efficiency of functioning of a hotel enterprise in a crisis is a combination of business processes, accounting of internal and external factors influencing the crisis, as well as constant assessment of the effectiveness of the existing strategy at the level of organizational structure, marketing, management system of the enterprise as a whole.

\section{MODERN TENDENCIES OF HOSPITALITY DEVELOPMENT \\ BUSINESS}

Currently, new conditions and trends are emerging, which largely determine the efficiency and competitiveness of hotels in times of crisis (Table 1). (Zemlina, Y., \& Lifirenko, O., 2019; Kobyak, V., \& Lvovna, I., 2015).

Hospitality business, like any other, depends on external factors, globalization processes, and scientific and technological progress, the latest modern technologies fundamentally change the model of consumer behavior, their preferences, and the conditions of functioning of enterprises. It should be noted that in the paradigm of the interaction of the hotel enterprise, both with external and internal factors, there is a crisis, which can be caused by:

- quality of services provided;

- market demand;

- $\quad$ price for the service;

- the material base of a hotel enterprise.

- external factors that do not depend on the hotel sector (military action, natural disasters, etc.). 
Table 1 Tendencies of hotel business development

\begin{tabular}{|c|c|}
\hline Tendency & Description \\
\hline $\begin{array}{l}\text { Strengthening the } \\
\text { role of particular } \\
\text { sectors of the } \\
\text { economy }\end{array}$ & $\begin{array}{l}\text { According to expert estimates, in the future, the hotel will mainly serve the } \\
\text { luxury market and the group market, while the focus of private and business } \\
\text { travel will shift to rental services }\end{array}$ \\
\hline $\begin{array}{l}\text { Development of new } \\
\text { forms of hotels }\end{array}$ & $\begin{array}{l}\text { A vivid example of this trend is the creation of capsule hotels, first opened } \\
\text { in Japan in } 1979 \text { and already presented in the Ukrainian hotel services } \\
\text { market. }\end{array}$ \\
\hline $\begin{array}{l}\text { Development of } \\
\text { robotic technology } \\
\text { and the introduction } \\
\text { of infrared sensors }\end{array}$ & $\begin{array}{l}\text { For example, AloftCopertino offers messenger service. Communication of } \\
\text { guests with the robot is carried out by means of the robotic mechanism } \\
\text { "A.L.O. Botlr" with } 4 \mathrm{G} \text { support, WI-FI module and a } 7 \text {-inch tablet. The use } \\
\text { of infrared sensors helps staff to make decisions, such as when they need } \\
\text { to clean a room }\end{array}$ \\
\hline $\begin{array}{l}\text { Implementation of } \\
\text { innovative software } \\
\text { products }\end{array}$ & $\begin{array}{l}\text { Products for Hotel Enterprises - SAAS Technology (Cloud). The main } \\
\text { advantage of such technologies is the lack of requirements for the purchase } \\
\text { of expensive equipment and software. Access to the system is via an } \\
\text { Internet browser from anywhere in the world }\end{array}$ \\
\hline $\begin{array}{l}\text { Mobile Marketing } \\
\text { development and } \\
\text { orientation on } \\
\text { "millennium" } \\
\text { generation }\end{array}$ & $\begin{array}{l}\text { Mobile applications have been successfully used to optimize interaction } \\
\text { with hotel guests (reservations, food reservations, taxis, etc.), as well as for } \\
\text { internal interaction of hotel staff (for example, the task of rooms cleaning, } \\
\text { and after cleaning the maid sends a message about the readiness of the } \\
\text { room to check and before new guests arrive) }\end{array}$ \\
\hline $\begin{array}{l}\text { Improvement of hotel } \\
\text { business service }\end{array}$ & $\begin{array}{l}\text { Encourages the hotel business representatives to offer extended content of } \\
\text { the hotel services offered, to enhance the service component in their work }\end{array}$ \\
\hline $\begin{array}{l}\text { Globalization and } \\
\text { integration of the } \\
\text { hotel business }\end{array}$ & $\begin{array}{l}\text { Creation of tourist corporations and hotel chains. There are well-known } \\
\text { international hotel brands in the Ukrainian market (Radisson SAS, Hilton, } \\
\text { Wyndham Hotel, HELIOPARK Group, InterContinental Hotels Group, and } \\
\text { others) }\end{array}$ \\
\hline $\begin{array}{l}\text { Accounting of tourist } \\
\text { flow peculiarities }\end{array}$ & $\begin{array}{l}\text { Accounting for the heterogeneity of the flow and the factors that form it, } \\
\text { allows you to offer the market needed for quality, volume and quantity of } \\
\text { services and to combat the factor of "seasonal demand" }\end{array}$ \\
\hline $\begin{array}{l}\text { Deep personalization } \\
\text { of service and } \\
\text { complete } \\
\text { concentration on } \\
\text { customer requests } \\
\text { and needs }\end{array}$ & $\begin{array}{l}\text { It is manifested in the presence of a wide range of additional services, in } \\
\text { the use of RFID technology, which identifies the guest before the service is } \\
\text { provided (TouchPoint from OneLabSolutions), biometric identification, } \\
\text { electronic lock systems, the use of the principle of greening in the } \\
\text { automation of life support systems. }\end{array}$ \\
\hline
\end{tabular}

\section{ANALYSIS OF THE STATE OF HOTEL BUSINESS IN UKRAINE}

The President's statements about the legalization of the gambling business, the talk about the Ukrainian promotional company and the search for the right hotel concept are the topics that are currently actively discussing the entire hotel real estate market. Despite the crisis period and the undeniable decline in the activity of foreign tourists at the beginning of the year, the sector does not lose hope to finish 2019 with good indicators.

During the first half of 2019, it was a lack of guests at all Ukrainian hotels. This is not surprising: on the one hand, the declared state of war has cut down the ranks of those wishing to see Ukraine, 
then the election is one, the election is the other business activity has dropped significantly, which immediately affected the average occupancy of the rooms. Thus, according to CBRE Ukraine analysts, according to the results of 8 months of 2019 , the average occupancy rate of Kyiv hotels was $54.1 \%$. The highest occupancy rate was observed in the period April-July when it averaged $58.8 \%$. The elections were over, and with them came a certain understanding of the vectors of further movement. (CBRE Ukraine, 2019).

According to Cushman \& Wakefield in Ukraine, the most turbulent period has affected 4-5-star hotels. Consumption for this category dropped to $43 \%$ from $46 \%$. It is important to note that this trend is explained by the seasonality factor. Since the Kyiv hotels are mainly focused on the business segment, the summer period is characterized by a lull, but since the autumn business activity increases, and by the results of the year, the overall figures can even become equal. (Cushman \& Wakefield, 2019).

To explain the decline in the occupancy of this category is quite simple: you will not find tourists for all the hotels in this class. At least now, when Ukraine is not yet popular enough for a foreign guest, including business players. It is well known that this category of visitors is designed for "fours" and "fives". First, crowds of international investors have not yet rushed to us, and those who come have already chosen permanent hotels. Second, the strengthening of the hryvnia against the dollar reduces the attractiveness of such hotels for foreign tourists in the context of room rates. On the other hand, the strengthening of the national currency is a positive factor for domestic tourists, which has a positive impact on the operating results of mid-range and economy hotels.

Investors are now forced to more practical approach the segments and pay attention to the economy in the first place. Confidently developing budget hotels - 3 stars, $3+$. First of all, because not only foreigners but also domestic tourists and businessmen can stay in such hotels, as the practice has shown. However, in some regions, there is already a demand for 4-star hotels."

Despite some variations and smaller hotel occupancy rates in some places and regions, the market as a whole is showing good financial results and a trend towards further growth. The statements of the President of Ukraine on the legalization of gambling and construction of new resort cities will accordingly lead to the increased interest of investors in new hotel projects. In addition, if the relevant tourism reforms are implemented and the budget allocated to the promotion of Ukraine as a tourist destination abroad, we will see even greater investment expectations in the hotel segment.

According to CBRE Ukraine, the average cost per room (ADR) in Kyiv was $\$ 80(-2.3 \%)$. The average rate of return of a single room (RevPAR) was $\$ 43(-5.3 \%)$, which is associated with lower demand for rooms. Thus, as of the end of August 2019 , since the beginning of the year, the total number of rooms sold was 826362 rooms, whereas in the previous period last year 836874 rooms were sold in Kyiv. (CBRE Ukraine, 2019).

Cushman \& Wakefield in Ukraine noted that for the luxury category, upper-upscale, upscale there was an increase of 4 to $22 \%$ in the first two quarters of 2018. It decelerated to $5 \%$ by the third quarter of 2018 , and at the end of 2018 - the beginning of 2019 has changed to a $20 \%$ decrease in room rates on average in dollar terms period to period.

The midscale and economy categories showed the opposite dynamics, as they showed an increase in the average price per room in all periods from the first quarter of 2018 to the second quarter of 2019, with growth being stable, which is explained by the greater opportunity for growth due to the low base for comparison and, accordingly, great potential and margin of safety in the segment. It is important to note that despite the contradictory trends of the first half of 2019 if we compare the price dynamics for the room with 2017, it is positive. (Cushman \& Wakefield, 2019).

While Kyiv is looking for new ways to attract foreign tourists, the regions are living their lives. Domestic tourists dominate there, for whom the seasonality factor still plays a role. Change this attitude hotels of new formats are capable, where they offer a comprehensive service, quality service, interesting entertainment regardless of the time of year. 
Uzhgorod, Chernivtsi, Lviv, Chernihiv, Kyiv, Odesa are the most attractive cities for tourists. The reconstruction of 4 buildings, which will become the Best Western Plus Market Square hotel for 70 rooms, is underway in Lviv. It is also possible to highlight the growing market image in the region of Bukovel-Yaremche-Skhidnytsia and Transcarpathia. The Black Sea and Azov regions are actively but not professionally developed (without the involvement of experts and the use of world experience).

It is particularly interesting that in Western Ukraine, a number of political events and decisions have had a much greater impact on the market. Many projects have been terminated and hotel real estate players have chosen waiting positions.

According to Glory Hotels Group, in Transcarpathia, since the beginning of six months, there has been some market downturn, in particular, because of the military conditions in Ukraine. In winter, the occupancy rate of hotels is less than $30 \%$, which is a very unfortunate situation with the pricing policy that has been in the region for the last three years. This is heating, snow removal, service and more. The download was minimal, which caused the hotel owners to sell their assets. The situation changed somehow at the end of June, prices started to rise and the average room rate increased to $\$ 23$ per day for 2 people without food."

Major players in the hotel market of the country say that the coldness of investors is easily explained by the fact that the payback period of the project is from 5 to 13 years, depending on the correct location, effective concept, technologically correct project, the expertise of the team that manages the business. $\mathrm{ROI}$ rate is $7-13 \%$. This interval has not undergone significant changes over the last 2 years, as the market conditions are relatively stable and inflation processes are observed, both in the expenditure part and in the revenue side, balancing each other. Still, there is a lack of a professional approach in the market and experts (consultants, technologists, etc.) involved in the project immediately.

Among the major drivers of the sector, which boomed in the first half of the year, hotel market players and experts call the steady increase in the attractiveness of Ukraine in the eyes of foreign tourists. There are many factors contributing to this, but the state-owned promotion campaign has not been well-considered and well-defined. We still do not have one. All outside advertising is created rather by the forces of different people, organizations, as well as the business itself. These are all separate voices that need state-level support and support.

Over the last year, Ukraine has achieved the highest growth in the region by the TTSI index, rising by 10 points and taking $78^{\text {th }}$ place. Ukraine has improved its business climate (from 124 to 103 places), security indicator (from 127 to 197 places), openness to foreigners (from 78 to 55 places) and general infrastructure (from 79 to 73 places). In general, the main task of industry development is the active participation of the state in the strategy of comprehensive support to the sector. (Glory Hotels Group, 2019).

In our opinion, one of the urgent problems is the lack of promotion of tourist attractions of Ukraine abroad at the interstate level, the lack of privileges and supporting programs for the development of various hotel segments. Lack of major congresses and assemblies in major cities, as well as poor development of transport infrastructure and very poor quality of Ukrainian roads.

As it is noted by Marina Leo, partner DEOL Partners, CEO of 11 Mirrors Design Hotel and Senator Hotels and Apartments, "I am confident that it is not adding strength to the hotel segment and adopted Law on Amendments to the Tax Code of January 1, 2019. It introduces new rates for tourist tax and rules for its management. In the future, the entire hotel sector may experience these changes. After all, the rate is charged not on the cost of settlement, but on the minimum wage, which increases every year. Therefore, the conditions for tourists are constantly changing, and any changes cause a negative reaction in people. Moreover, this is especially felt in the segment of hostels and low-cost accommodation." (Property Times, 2019, Jan. 11).

In addition, unlike many developed European countries, we still do not have a reduced tax rate on services related to the temporary 
accommodation of tourists. It remains at $20 \%$, although lowering the rate will help attract investment, create new jobs, grow the industry and improve the business climate and economy of the country as a whole. We are convinced that the more tourists the country receives, the higher is income and lower are costs.

CBRE Ukraine cites the latest World Tourism Council study on Ukraine. According to it, the direct contribution of the tourism industry to the GDP of Ukraine amounted to $1.5 \%$ of the total GDP in 2017, and given the growth forecast for 2018-2028, this figure will reach $1.7 \%$ of GDP in 2028. For comparison, in France, the direct contribution of the tourism industry to the country's GDP was $3.6 \%$ in 2017 , with a forecast of $4.0 \%$ in 2028 (CBRE Ukraine, 2019).

Hotel business experts are convinced that the second half of 2019 may be the best for the hotel's real estate market. First, it is expected that the market will gradually develop in the future, taking into account the positive trends in the economy and improving economic expectations. Economic expectations indicator, which reached $111.5 \%$ at the end of Q3 2019 (+ 9p since the beginning of the year). The opening of new destinations for international flights at Boryspil and Kyiv airports will help to improve the situation in the industry.

According to the statistics of the State Aviation Service for January-August 2019, the volume of passenger transportation of Ukrainian airlines increased by $10.7 \%$ compared to the corresponding period of the last year and amounted to 9.2 million people, including international ones - by $10.9 \%$ and amounted to 8.4 million people. Passenger flows through Ukrainian airports increased by $19.4 \%$ to over 16 million people, including in the international connection by $20.7 \%$ and amounted to 14.5 million people. (State Aviation Service of Ukraine 2019).

However, given the $1.1 \%$ decline in hotel occupancy, the key challenge for the hotel industry is now the development of tourist attraction in Ukraine and Kyiv in the world, when hotel occupancy will be achieved not only through business travel but also through leisure travelers who are interested in sightseeing. With regard to the forecast by the end of this year, there are no significant changes in the operating figures of hotels, and the occupancy rate will remain in the range of $57-59 \%$. The overall supply in the hotel real estate market will also remain unchanged since the new offer by the end of the year consists of small hotels.

Traditional hotels will face significant competition from trendsetter hotels: capsule hotels, as well as interesting hostel concepts. (CBRE Ukraine, 2019).

Hostel development is the current trend in the hotel real estate market and is currently attracting investors. We see that a number of hostels have been recently opened in Kyiv. However, it is important to keep in mind that hostels are an intermediate budget segment that market players fall into until political situation is clear.

At Cushman \& Wakefield in Ukraine, one of the major trends that will affect the situation in the sector is mentioned the increasing role of the Internet in making consumer preferences and habits because in the world it is already difficult to find at least one tourist who does not use Google Maps, Amazon, Booking, Tripadvisor, etc. (Cushman \& Wakefield, 2019).

In addition, the old formats of hotels that offer only bed and breakfast will remain overboard. The trend includes additional value and additional services, including co-workings. For example, Accor Hotels has announced plans to open cobranding hotels in the WOJO brand. It is a shared space located in bars, restaurants, and the hotel lobby. The target audience of this project is business travelers and freelancers. Bleisure Travel by Millennials is a name given to travel that combines business goals with leisure and is becoming more and more popular, especially among the millennial generation. For example, travelers may first attend a business meeting or conference, but then extend their stay to turn it into a leisure destination. 
4 HOTEL MANAGEMENT METHODS IN CRISIS

In order to solve the problems related to the issues of functioning of the hotel enterprises under the conditions of crisis, we have offered the following methods, which are presented in Table. 2.

Table 2 Hotel management methods in crisis (Groh, M., 2014)

\begin{tabular}{|ll|ll|}
\hline \multicolumn{2}{|c|}{ Tactical methods } & \multicolumn{2}{|c|}{ Strategic methods } \\
\hline 1. & Restructuring & 1. & Merger \\
2. & Reduction & 2. & Innovations \\
3. & Bankruptcy & 3. & Regulation \\
& & 4. & Restructuring \\
& & 5. & Reduction \\
\hline
\end{tabular}

The first group of methods includes tactical methods. In turn, tactical methods include restructuring, reductions, and bankruptcy. These methods are aimed at the rapid improvement of the financial performance of the enterprise, i.e. overcoming crisis consequences. However, the use of these methods is not always sufficient to eliminate the causes of the crisis.

Another group of methods is strategic. As a rule, hotel managers will not immediately be able to see the results from these methods, but their use changes quality characteristics such as competitiveness, investment attractiveness, customer focus, and innovation.

The main methods include mergers within one network of enterprises at different stages of development and distribution and diversification of activities. This method may be rational if the integration results in significant savings or possible reductions, such as transportation costs.

Innovation is the introduction of modern strategic management approaches in times of crisis. Regulation, in turn, involves the formation of strategic planning and management reporting, the creation of a combined system of financial control and planning, automated accounting systems and the formation of effective marketing activities. These approaches address many of the problems associated with market conditions and the search for new clients and partners in the international market.

Restructuring is a complex method of crisis management that has become widespread in recent times. This method involves changing the organizational structure and strategic management system.

The method of restructuring business processes leads to the reduction of unnecessary links and unnecessary costs of time and money and provides a dramatic increase in the efficiency of activities, such as efficiency, processing time, production costs, etc.

The reduction is another way that can immediately improve the performance of the hotel industry. This is a reduction in overcapacity and a reduction in staff employment in line with real market demand. This method leads to a significant reduction in costs and lower production prices. For example, the hotel and restaurant sector in the UK has about $98.3 \%$ of businesses with fewer than 50 employees.

Effective strategic management during a crisis involves a combination of the following elements: the professional knowledge of the employees of the strategic management organization; experience of the anti-crisis activity.

The success of strategic crisis management depends on the timely detection of crises and the application of the most effective methods to overcome it.

Effective functioning in times of crisis is carried out using a number of strategic and tactical methods of strategic management in the aggregation.

\section{MODEL OF HOTEL ENTERPRISE OPERATION IN CRISIS}

The period when the hotel business experiences some "stagnation" is the perfect time to work on optimizing it. Most leading experts believe that the main purpose of such a procedure should be to reduce overall costs while maintaining the same quality of service. 
Stages of the analysis of a condition of the hotel enterprise under the terms of crisis

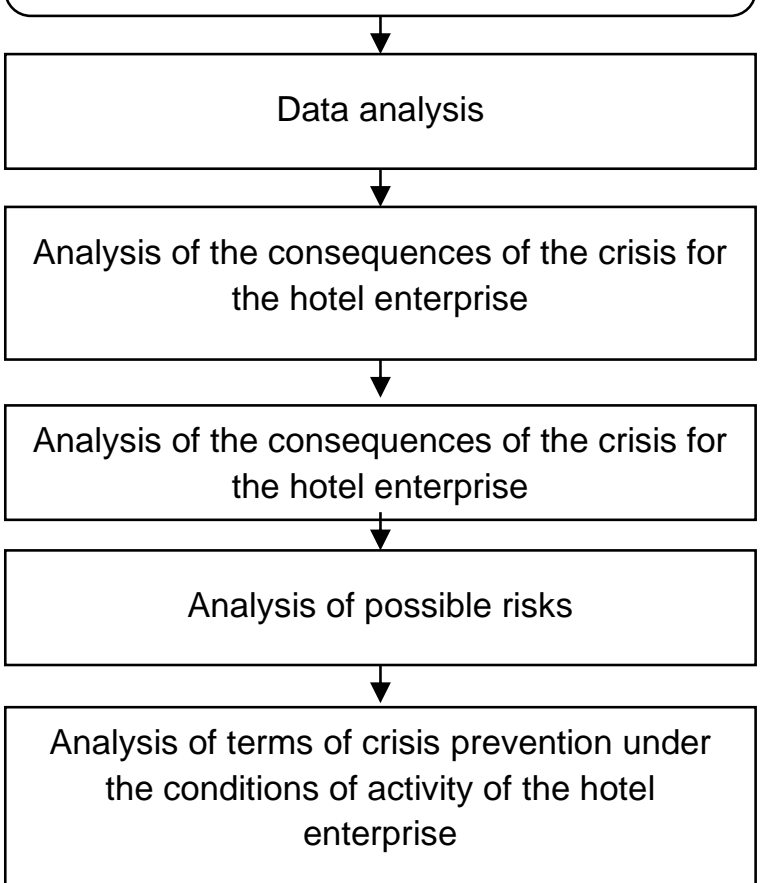

Let's consider a systematic process of analyzing the state of affairs in crisis management (Fig. 1).
As a result, the following steps can be identified: data analysis (including financial, commercial and service audits); the possible impact of the crisis on the hotel business; possible steps to overcome the crisis; potential risk factors for these actions; terms of implementation of "recovery" events.

Also, the analysis of current affairs of the hotel enterprise can be carried out using an evaluation matrix (table. 3), which represents the main "areas" of the studied business, determined the initial degree of significance (specific gravity), where the manager of the hotel enterprise must evaluate on a 10-point scale each sphere. The total is calculated as the product of the scale and specific gravity score.

Fig. 1 Stages of analysis of the state of hotel enterprise in a crisis (Kizyan, N., \& Melyakova, E., 2015)

Table 3 Example evaluation matrix for each alternative (developed by the authors)

\begin{tabular}{|l|c|c|c|c|c|c|c|c|c|c|c|c|c|}
\hline \multirow{2}{*}{ Potential } & \multirow{2}{*}{ Share } & \multicolumn{7}{|c|}{ Scale } & \multirow{2}{*}{ Result } \\
\hline & & 0 & 1 & 2 & 3 & 4 & 5 & 6 & 7 & 8 & 9 & 10 & \\
\hline Management & 0.3 & & & & & + & & & & & & & 1.2 \\
\hline Finance & 0.2 & & & & + & & & & & & & & 0.6 \\
\hline HR & 0.2 & & & & & & + & & & & & & 1.0 \\
\hline Marketing & 0.1 & & & & & & & + & & & & & 0.6 \\
\hline Purchase & 0.1 & & + & & & & & & & & & & 0.1 \\
\hline $\begin{array}{l}\text { Sales of services } \\
\text { (products) }\end{array}$ & 0.1 & & & & & + & & & & & & & 0.4 \\
\hline & 1 & & & & & & & & & & & & 3.9 \\
\hline
\end{tabular}

Thus, it should be noted that the "share" of management is the most significant factor in times of crisis, which solves the problems of the enterprise through crisis management.

Crisis management in business is called a complex of management decisions that are aimed at preventing and overcoming the negative effects of the enterprise. In times of crisis, it is actually about adapting all the hotel's activities to the new economic conditions.

In our opinion, the implementation of crisis management, which is the basis of functioning in the hotel business in times of crisis, should be divided into several stages (Fig. 2). 


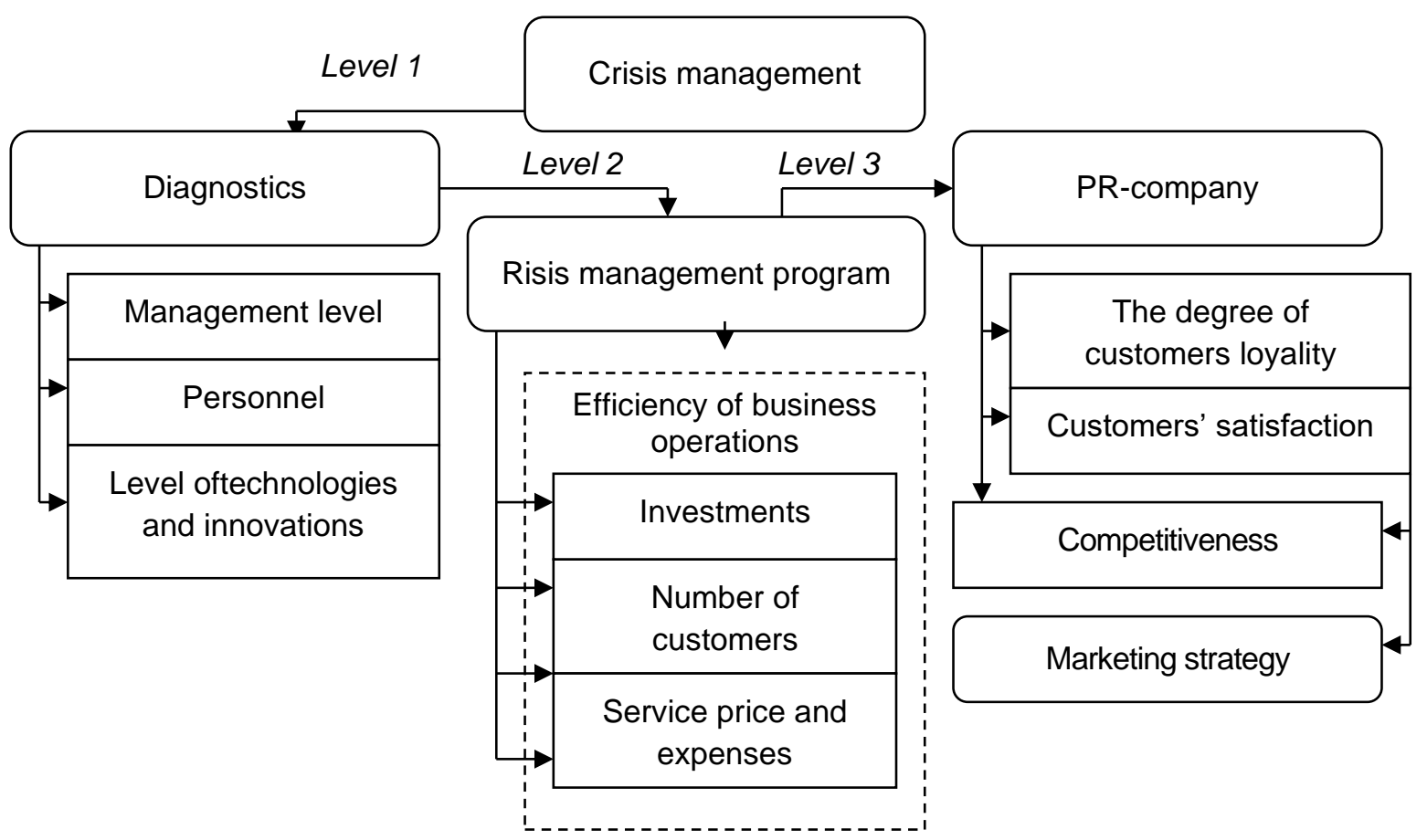

Fig. 2 Model of the functioning of the hotel enterprise in times of crisis (developed by authors)

Let's consider a phased implementation of crisis management activities.

I. Diagnosis. There are three groups of characteristics to diagnose the state of affairs in a hotel enterprise. The first is the basic elements of doing business: the level of management, staff and the level of adaptability and business innovation. For example, when talking about the hotel team, the interest should be the organizational structure, its effectiveness, the lack of duplicate functions. In particular, the manager should know how many people he works for per room. Typically, in 3-star hotels, there is no more than one person, and in 5-star hotels, the figure can range from 1.5 to 2.5 people in deluxe hotels. Comparing its own indicator with the average market, the company understands whether it works effectively or not. In addition to statistics, management needs to analyze the level of competence of staff, the degree of satisfaction of people with their work, motivational measures.

II. Crisis management program. The second niche in which to diagnose in times of crisis is the efficiency of business processes in a hotel enterprise. There are a number of parameters that can be used to analyze operating activities. For example, how much the costs incurred in operating a business can be compared to the revenue generated by a hotel; the extent to which the number of people employed in a particular site is appropriate; how effectively the services of one or the other services of the hotel enterprise are sold. (Kobyak, V., \& Lvovna, I., 2015).

III. PR campaign. The third level of diagnostics is the market indicators of the functioning of hotel enterprise, the degree of customer loyalty to the hotel, their satisfaction with the quality of service, the competitiveness of the services offered. Correcting the situation at this level, if the opportunities of the other two were missed, is much more difficult, since the hotel company may already lose its market share, which will undoubtedly affect the profitability indicators.

If the negative effects affect the financial efficiency of the hotel, it loses profit, and therefore profitability has inadequate liquidity indicators. Business rehabilitation measures are aimed at restoring the solvency of the hotel business. This is also a debt restructuring if there are difficulties in repaying loans, improving the liquidity of the hotel's resources, closing the cash gaps, optimizing costs.

PR campaigns also include an effective marketing strategy to attract customers with minimal investment and maximum profit. In this case, the following promotion channels take place when 
advertising hotel companies: discounts and promotions for regular and newcomers for the purpose of resale; advertising in the media; cooperation with airports, airlines, large shopping centers; distribution of leaflets, flash mobs in crowded places; Internet marketing.

It is worth noting that the situation in the hotel industry of Ukraine, complicated by the existing hostilities in the east of the country, forces managers to monitor trends and innovate in order to attract tourists at all costs.

Thus, the above functional model will allow having an idea of the necessity of measures during the crisis of the hotel enterprises, a basic set of actions where each individual hotel business will undoubtedly have its own peculiarities depending on the causes of the crisis.

\section{CONCLUSIONS}

The hotel industry is an important business globally, and current trends and tourism demand are changing it. Numerous trends emphasize the importance of modern hotel business, as the modern tourist is not only satisfied with the basic offers in hotel service but also requires a differentiated and personal service, which becomes the main motive for travel. Because of the existing and ever-expanding variety of hotel complexes, competition is growing in which businesses need to survive. As a result, the operation of hospitality enterprises in times of crisis is a fundamental goal for maintaining the value of the hospitality industry. In the framework of this study, the tendencies of development of the hotel enterprises of Ukraine are revealed and the model of management of the enterprise of the hotel industry during the crisis is developed, which has the basic set of actions necessary for the improvement of the crisis.

\section{WORKSCITED}

CBRE Ukraine. (2019). A brief overview of the hotel real estate market in Kyiv for the first half of 2019. Retrieved from: https://cbre-expandia.com/analitika/ (accessed 3 December 2019).

Cushman \& Wakefield. (2019). Market Overview of Ukraine for the 1st half of 2019. Retrieved from: https://cushmanwakefield.com.ua/ru/ukraina-1-pol-2019-g (accessed 3 December 2019).

Glory Hotels Group. (2019). The hotel market of Ukraine in the eyes of a foreign tourist. Retrieved from: http://gloryhotels.group/uk/novosti (accessed 3 December 2019).

Groh, M. (2014). Strategic management in times of crisis. American Journal of Economics and Business Administration, 6(2), 49-57.

Kizyan, N., \& Melyakova, E. (2015). Directions of enterprise development in a crisis. PSEH [PSE], 4(56), Retrieved from: https://cyberleninka.ru/article/n/napravleniya-razvitiya-predpriyatiy-v-usloviyahkrizisa (accessed 5 December 2019).

Kobyak, V., \& Lvovna, I. (2015). The competitiveness of hotel facilities. Theory and practice. Journal of Environmental Management and Tourism, VI, 2(12), 374-381.

Kopia, J., Just, V., Geldmache, W., \& Bußian, A. (2017). Organization performance and enterprise risk management. Ecoforum, 6, 1, 1 .

Property Times. (2019, January 11). Tourist tax in a new way: what will change and how it will affect the hospitality industry. Retrieved from: https://propertytimes.com.ua/gostinichnaya_nedvizhimost/ turisticheskiy_sbor_ponovomu (accessed 3 December 2019).

Shad, K., \& Fong Woon, L. (2015). Conceptual Framework for Enterprise Risk Management performance measure through Economic Value Added, Global Business. Management Research, 7(2), 1.

State Aviation Service of Ukraine. (2019). Up-to-date information on key performance indicators of the aviation industry for January-November 2019. Retrieved from: https://avia.gov.ua/pronas/statistika/operativna-informatsiya/ (accessed 3 December 2019). 
Essays, UK. (November 2018). The three phase model of Crisis. Retrieved from https://www.ukessays.com/essays/management/the-three-phase-model-of-crisismanagement-essay.php?vref=1 (accessed 20 November 2019).

Zemlina, Y., \& Lifirenko, O. (2019). Trends in hotel business development in Ukraine". Restaurant and hotel consulting. Innovation Res Restaurant and hotel consulting. Innovation, 1(2), Retrieved from: http://nbuv.gov.ua/UJRN/rhci_2019_2_1_11 (accessed 31 November 2019).

Received for publication:

24.12.2019

Revision received:

07.01 .2020

Accepted for publication:

10.01.2020

\section{How to cite this article?}

Style - APA Sixth Edition:

Bagrii, K., \& Palamarek, K. (2020, January 15). Tendencies for the development of hotels in Ukraine under crisis situations. (Z. Cekerevac, Ed.) MEST Journal, 8(1), 25-35. doi:10.12709/mest.08.08.01.04

Style - Chicago Sixteenth Edition:

Bagrii, Konon, and Karina Palamarek. 2020. "Tendencies for the development of hotels in Ukraine under crisis situations." Edited by Zoran Cekerevac. MEST Journal (MESTE) 8 (1): 25-35. doi:10.12709/mest.08.08.01.04.

Style - GOST Name Sort:

Bagrii Konon and Palamarek Karina Tendencies for the development of hotels in Ukraine under crisis situations [Journal] // MEST Journal / ed. Cekerevac Zoran. - Belgrade - Toronto : MESTE, January 15, 2020. - 1 : Vol. 8. - pp. 25-35.

Style - Harvard Anglia:

Bagrii, K. \& Palamarek, K., 2020. Tendencies for the development of hotels in Ukraine under crisis situations. MEST Journal, 15 January, 8(1), pp. 25-35.

Style - ISO 690 Numerical Reference:

Tendencies for the development of hotels in Ukraine under crisis situations. Bagrii, Konon and Palamarek, Karina. [ed.] Zoran Cekerevac. 1, Belgrade - Toronto : MESTE, January 15, 2020, MEST Journal, Vol. 8, pp. 25-35. 